\title{
Optimalisasi Pengelolaan Anggaran, Hindari Krisis Fiskal
}

\author{
Jaka Sriyana
}

For the first of long term development, Indonesia has achieved successfully the high rate of economic growth. It was caused by the government's effective economic policy. In this period the government applied a deficit fiscal, in which total expenditure is over domestic income. In fact, the value of deficit tends to be higher each year. A high of deficit fiscal was indicated by strongly increase in both routine expenditure and public investment. Uncontrolled deficit fiscal policy and increasing of government expenditure has negative effects, there were a low efficiency of fiscal management, the higher expenditure leaked, the high cost economy and the huge of foreign debt. To overcome these problems the government must create the new sources of revenue and enlarges tax reform.

\section{Pendahuluan}

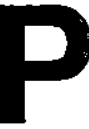

embangunan ekonomi merupakan suatu proses untuk mencapai kesejahteraan masyarakat. Keberhasilan pembangunan ekonomi sangat dipengaruhi oleh pola kebijakan ekonomi yang dilakukan oleh pemerintah. Ada dua macam kebijakan ekonomi yang utama, yaitu kebijakan moneter dan kebijakan fiskal. Kebijakan moneter adalah kebijakan ekonomi yang dilakukan oleh pemerintah dengan cara pengendalian sektor moneter, khususnya jumlah uang beredar, sedangkan kebijakan fiskal adalah kebijakan ekonomi yang dilakukan oleh pemerintah dengan cara pengendalian anggaran (APBN). Penerapan kebijakan moneter tanpa diimbangi kebijakan fiskal dan pembenahan sektor riil justru akan menimbulkan spekulasi bisnis (Karseno, 1997: 21). Dalam perkembangan selama tiga dasa warsa pembangunan ekonomi di Indonesia telah menunjukkan hasil yang cukup berarti, jika dilihat dari sudut pandang ekonomi. Indikator-indikator ekonomi makro telah mengalami perubahan yang cukup besar dalam kurun waktu tersebut. Pertumbuhan ekonomi sebagai salah satu indikator utama keberhasilan pembangunan ekonomi di Indonesia menunjukkan perkembangan yang cukup besar. Tentu saja semua ini diperoleh dengan suatu bentuk managemen tertentu yang dilakukan oleh pemerintah yang berkuasa saat itu. Namun demikian keberhasilan tersebut bukannya tanpa 
masalah. Inflasi yang relatif tinggi mendekati $10 \%$, dan merosotnya nilai tukar merupakan indikator yang mencerminkan kelemahan managemen makroekonomi selama itu. Masalah lain adalah ketergantungan pembiayaan pembangunan pada sektor luar negeri, khususnya hutang luar negeri yang selalu memunculkan masalah baru sebagai dampak negatif dari ketergantungan tersebut. Masalah lain adalah pengelolaan anggaran yang kurang optimal sehingga menimbulkan ketidakefisienan anggaran. Data pada tabel 1 menunjukkan beberapa indikator makroekonomi pada beberapa tahun.

Tabel 1.

Beberapa Indikator Makroekonomi Indonesia

\begin{tabular}{|l|c|r|}
\hline \multicolumn{1}{|c|}{ Keterangan } & Tahun & Besaran \\
\hline Laju GDP (\%) & $1980-1990$ & 6,3 \\
Inflasi (\%) & $1990-1997$ & 7,6 \\
Pengeluaran Pemerintah & $1985-1997$ & 8,8 \\
(Milyar Rupiah) & 1985 & 19.383 \\
Defisit Fiskal (\%GNP) & 1995 & 79.215 \\
& $1990-1990$ & \\
Hutang/GNP (\%) & 1980 & 2,3 \\
& 1995 & 0,6 \\
Deficit Current Account & 1980 & 28,0 \\
(\% GNP) & 1995 & 56,9 \\
ICOR & $1992-1997$ & 3,3 \\
\hline
\end{tabular}

Sumber: Dirangkum dari beberapa sumber.

\section{Defisit Anggaran \\ dan Perkembangan Pengeluaran Pemerintah}

Dalam menjalankan kebijakan makroekonomi, khususnya kebijakan fiskal, pemerintah mengadopsi prinsip anggaran berimbang, namun dalam pengertian ekonomi kebijakan yang dimaksud merupakan kebijakan defisit. Kebijakan tersebut tidak lain adalah untuk mengendalikan situasi ekonomi yang

tengah dilanda ketidakstabilan dan untuk merangsang pertumbuhan sektor swasta. Sejak saat itu sektor pengeluaran pemerintah mengalami kenaikan yang tajam. Selama dasa warsa 1965-1975 pengeluaran pemerintah telah meningkat dua kali lipat. Bahkan hingga tahun 1991 telah mengalami kenaikan sebesar 24 kali lipat. Namun 
kenaikan yang paling pesat terjadi pada awal tahun 1980-an. Hal ini disebabkan oleh ketersediaan dan dari sumber migas serta adanya keinginan pemerintah untuk mencapai target pertumbuhan ekonomi lebih dari $5 \%$ pertahun.

Kebijakan peningkatan pengeluaran pemerintah pada awal tahun 1970-an ternyata telah mengakibatkan mengalirnya bantuan dari luar negeri, sehingga terjadi peningkatan investasi yang sangat besar (Hill, 1996:65). Implikasi berikutnya adalah mulai tumbuhnya kegiatan perekonomian sehingga pendapatan masyarakat meningkat. Keadaan tersebut ternyata juga disertai oleh keberhasilan pengendalian inflasi oleh pemerintah, sehingga peningkatan kesejahteraan masyarakat dapat dinikmati secara riil. Kebijakan pengeluaran pemerintah yang bersifat ekspansif tersebut terus dilanjutkan hingga pada tahun 1980an dan tahun 1990-an. Peningkatan pengeluaran pemerintah pada kurun waktu tersebut mencapai rata-rata 10 persen per tahun. Dampak kebijakan tersebut memang dapat dilihat dengan semakin meningkatnya pertumbuhan ekonomi, khususnya menjelang dan awal tahun 1990-an. Gambar 1 menunjukkan pola perkembangan pengeluaran pemerintah.

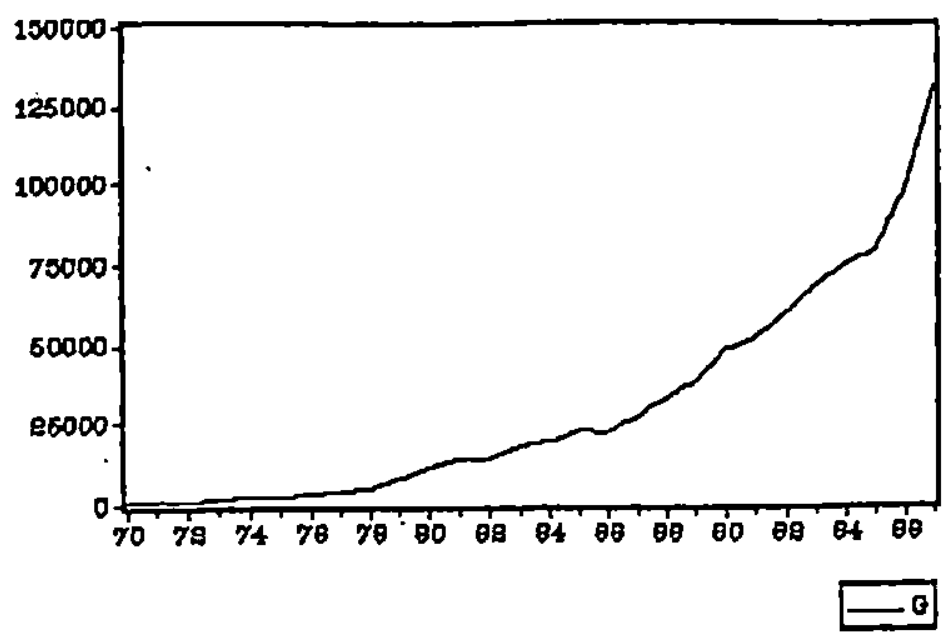

Gambar 1.

Pola Pengeluaran Pemerintah, 1969 -1997

Adanya kebijakan peningkatan pengeluaran pemerintah ternyata tidak diikuti oleh kemandirian dalam menggali sumber-sumber pendanaan pembangunan oleh pemerintah. Jika pada awal tahun tujuh puluhan pemerintah bisa mengandalkan sumber penerimaan dari migas, maka sejak awal tahun 1980 tidak bisa dilakukan lagi. Hal ini disebabkan adanya krisis dunia yang mengakibatkan turunnya harga minyak dunia sehingga penerimaan negara dari sumber tersebut mengalami penurunan yang cukup berarti. Situasi tersebut ternyata tidak mampu 
diimbangi oleh kenaikan pendanaan dari sumber lain khususnya pajak. Dilihat dari rasio antara pajak dan pengeluaran total masih menunjukkan angka yang relatif rendah, yaitu masih di bawah $60 \%$. Peningkatan yang cukup berarti baru terjadi pada tahun 1990-an, pada saat itu sumber pajak dari non migas telah mampu melampaui penerimaan dari migas. Kemampuan penerimaan dari dalam negeri, khususnya pajak menimbulkan semakin besarnya defisit anggaran yang dialami oleh pemerintah. Hal ini tentu saja membawa konsekuensi pada kebutuhan akan dana untuk pembiayaan pembangunan yang semakin besar pada periode berikutnya.

Dengan penetapan target pertumbuhan ekonomi yang relatif besar pada angka $5 \%$ pertahun telah membawa konsekuensi kebutuhan dana pembangunan yang besar, baik di sektor swasta maupun sektor pemerintah. Oleh karena keterbatasan sumber dana yang telah dijelaskan, maka pemerintah mengambil kebijakan untuk memperbesar hutang luar negeri. Kewajiban pengembalian hutang yang harus dibayar dengan mata uang asing, khususnya dollar AS dan yen telah membawa dampak kebutuhan akan mata uang tersebut meningkat pesat. Kondisi pelaku ekonomi ternyata tidak mampu menghimpun valuta asing untuk pembayaran hutang luar negeri sehingga permintaan lebih besar daripada penawaran. Dengan kata lain telah terjadi lack.valuta asing khususnya dollar AS. Kondisi inilah yang memberi kontribusi cukup besar pada terjadinya krisis ekonomi di Indonesia pada tahun 1997. Jadi dapat diambil suatu hubungan antara kebijakan fiskal khususnya pengeluaran pemerintah dengan kondisi makroekonomi di Indonesia. Dengan demikian dapat dikatakan bahwa pengendalian pengeluaran pemerintah sebagai bagian dari kebijakan fiskal harus dilakukan dengan menganut prinsip kehatihatian (prudent economic policy). Ekspansi dalam bidang pengeluaran pemerintah yang bertujuan pada peningkatan aktivitas ekonomi nasional dapat mengakibatkan terjadinya gejolak perekonomian nasional. Tabel 2 dan gambar 2 menunjukkan perkembangan defisit anggaran pemerintah. 
Topik: Optimalisasi Pengelolaan Anggaran, Hindari Krisis Fiskal, Jaka Sriyana

Tabel 2.

Defisit Anggaran, Pengeluaran Pemerintah dan

Perubahan Pengeluaran Pemerintah, 1985-1997

\begin{tabular}{|c|c|c|c|}
\hline Tahun & $\begin{array}{c}\text { Defisit Anggaran } \\
\text { (Miliar Rupiah) }\end{array}$ & $\begin{array}{c}\text { Pengel. Pem } \\
\text { (Miliar Rupiah) }\end{array}$ & $\begin{array}{r}\text { Perubahan } \\
\text { Pengel. Pem. }\end{array}$ \\
\hline 1985 & 3.572 & $19.637,4$ & $-924,5$ \\
1986 & 5.751 & $22.643,3$ & $3.005,9$ \\
1987 & 6.156 & $25.539,4$ & $2.896,1$ \\
1988 & 9.985 & $30.062,3$ & $4.522,9$ \\
1989 & 9.426 & $40.810,9$ & $10.748,6$ \\
1990 & 9.903 & $44.692,7$ & $3.881,8$ \\
1991 & 10.407 & $50.816,3$ & $6.123,6$ \\
1992 & 10.714 & $58.511,5$ & $7.695,2$ \\
1993 & 10.752 & $62,022,5$ & $3.511,0$ \\
1994 & 10.983 & $72.342,8$ & $10.320,3$ \\
1995 & 11.789 & $80.258,4$ & $7.915,6$ \\
1996 & 12.413 & $90.616,4$ & 10.368 \\
1997 & 23.817 & $131.544,6$ & 41.072 \\
\hline
\end{tabular}

Sumber: BPS Pusat, Jakarta, Nota Keuangan dan RAPBN 
Topik: Optimalisasi Pengelolaan Anggaran, Hindari Krisis Fiskal, Jakảisriyana

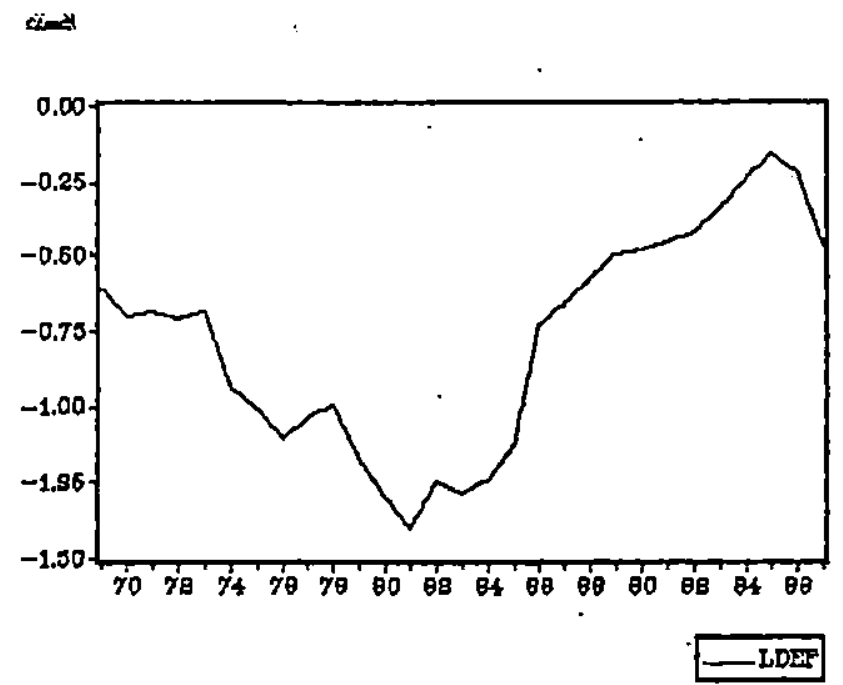

Gambar 3.

Perubahan Defisit Anggaran, 1969-1997

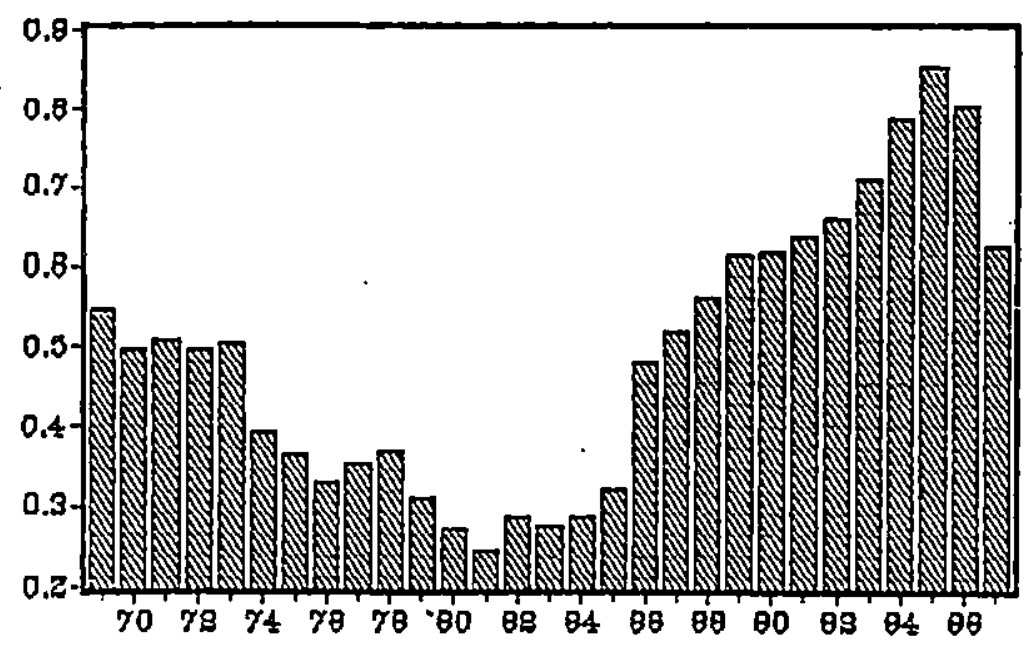

Gambar 4.

Rasio Penerimaan Pajak dan Pengeluaran Pemerintah, 1969-1997 
Topik: Optimalisasi Pengelolaan Anggaran, Hindari Krisis Fiskal, Jaka Sriyana

Pengelolaan anggaran yang mengandalkan pembiayaan dari luar negeri ternyata telah mengakibatkan perekonomian kita menjadi rentan sekali terhadap perkembangan makroekonomi dunia, khususnya perubahan nilai mata uang internasional. Puncak dari masalah tersebut adalah terjadinya krisis moneter pada tahun 1997. Tentu saja dengan adanya kejadian tersebut memaksa pemerintah untuk melakukan redesign atas kebijakan makroekonominya, khususnya berkaitan dengan pengelolaan anggaran. Hingga tahun 2001, permasalahan kemandirian pembiayaan pembangunan belum juga dapat diatasi oleh pemerintah. Nilai defisit anggaran masih cukup besar dan alternatif sumber-sumber pembiayaan pembangunan belum juga dapat digali. Tabel berikut menunjukkan pola sederhana APBN tahun 2000-2001.

Tabel 3.

APBN 2000-2001 (Milyar Rupiah)

\begin{tabular}{|c|c|c|c|c|}
\hline \multirow{2}{*}{ Komponen APBN } & \multicolumn{2}{|c|}{ Tahun 2000} & \multicolumn{2}{|c|}{ Tahun 2001 (Revisi) } \\
\hline & APBN & \%Thd PDB & APBN & \%Thd PDB \\
\hline $\begin{array}{l}\text { A. Pendapatan Negara } \\
\text { dan Hibah } \\
\text { 1. Penerimaan Perpajakan } \\
\text { 2. Penerimaan Bukan Pajak } \\
\text { B. Belanja Negara } \\
\text { C. Surplus/Defisit }\end{array}$ & $\begin{array}{r}152.896,5 \\
101.436,8 \\
51.459,7 \\
\\
197.030,3 \\
(44.133,8)\end{array}$ & $\begin{array}{c}16,8 \\
11,1 \\
5,7 \\
21,6 \\
4,8\end{array}$ & $\begin{array}{r}263.26,6 \\
\\
179.892,0 \\
83.334,6 \\
315.756 .1 \\
(52.529,5)\end{array}$ & $\begin{array}{r}18,4 \\
12,6 \\
5,8 \\
22,2 \\
3,7\end{array}$ \\
\hline $\begin{array}{l}\text { Asumsi: } \\
\text { 1. PDB (Milyar Rp) } \\
\text { 2. Pertumbuhan ekonomi (\%) } \\
\text { 3. IHK (Inflasi) } \\
\text { 4. Nilai Tukar (Rp/Dollar AS) }\end{array}$ & $\begin{array}{r}910.431,7 \\
. \quad 3,8 \\
4,8 \\
7.000\end{array}$ & & $\begin{array}{r}1.425 .000,0 \\
5,0 \\
7,0 \\
7.800,0\end{array}$ & \\
\hline
\end{tabular}

Sumber: Kompas, beberapa edisi.

\section{Kualitas Pengelolaan Anggaran}

Anggaran (budgef) pemerintah terdiri atas unsur penerimaan dan unsur pengeluaran. Dalam konsep ekonomi publik, sumber utama penerimaan negara adalah pajak di samping penerimaan dari hutang luar negeri dan sumber penerimaan dalam negeri lainnya, misalnya penjualan minyak dan gas bumi. Pengeluaran pemerintah ter- diri atas pengeluaran rutin dan pengeluaran permbangunan. Pengelolaan pengeluaran pemerintah yang tidak tepat justru akan merugikan perekonomian, yaitu terjadinya. inefisiensi nasional dan ilusi fiskal /fiscal (Beetsman and Ploeg, 1996; Miller and Russel, 1997). Permasalahan lain yang mungkin ditimbulkan oleh ketidaktepatan 
kebijakan fiskal adalah adanya crowding out sehingga justru akan menurunkan investási swasta (Chao and Yu, 1992; Dimsdale and Horsewod, 1995). Untuk menghindari permasalahan tersebut dituntut kehati-hatian dalam pengelolaan fiskal oleh pemerintah.

Selama tiga dasa warsa pemerintahan orde baru, pola kebijakan fiskal yang dilakukan adalah defisit. Hal ini bertujuan untuk menjaga stabilitas ekonomi dan peningkatan laju pertumbuhan ekonomi (Hill, 1996: 66; Dumairy, 1997: 167). Alàsan lain adalah, bahwa perkembangan selama sepuluh tahun terakhir juga menunjukkan bahwa kebijakan moneter belum membuahkan hasil yang memadai (Karseno, 1997: 22). Sejalan dengan kebijakan defisit fiskal tersebut ternyata dapat menyebabkan pengeluaran pemerintah total juga mengalami kenaikan tiap tahun (lihat juga Sheehey, 1993; Petrovic, 1994; Nunes and Stemitsiotis, 1995.

Kenyataan bahwa kebijakan defisit anggaran di Indonesia yang semakin besar serta peningkatan pengeluaran pemerintah yang mencapai rata-rata lebih dari 10 persen, menunjukkan komitmen pemerintah untuk mendorong perekonomian nasional dengan melalui kebijakan anggaran. Namun seperti telah dikemukakan sebelumnya, bahwa pengeluaran pemerintah total belum tentu mencerminkan keinginan (permintaan) masyarakat secara riil. Jika itu yang terjadi dapat menimbulkan alokasi pengeluaran yang tidak efisien (Shah, 1992; Walfson, 1993).

Kajian tentang pengeluaran pemerintah di Indonesia telah mendapat perhatian yang besar dari para ahli ekonomi. Kebanyakan penelitian yang berkaitan dengan pengeluaran pemerintah mengamati tentang dampaknya terhadap indikator ekonomi makro Indonesia (misalnya Adji, 1998:17 ; Handayani, 1997: 60-87; Mansoer dan
Soelistyo, 1998: 65-67). Kuncoro, (1999: 13) menemukan bahwa kebijakan pengeluaran pemerintah di Indonesia ternyata mengakibatkan penurunan investasi swasta yang signifikan. Syahrizal (1996: 50-65) meneliti tentang efisiensi pengeluaran pemerintah, khususnya tentang bantuan kepada daerah tingkat I dan tingkat II. Hasil yang diperoleh menunjukkan bahwa efisiensi pengeluaran pemerintah di Indonesia relatif rendah. Pengamatan tentang pengeluaran pemerintah yang telah dilakukan untuk kasus negara lain sudah cukup banyak. Bruno dan Smoiders (1994: 325-338) menganalisis tentang pengeluaran pemerintah untuk Netherland (Flemish) tahun 1994. Hasil yang ditemukan menunjukkan bahwa pertumbuhan pengeluaran pemerintah tidak menunjukkan adanya renter illusion di daerah yang diamati.

Kebijakan fiskal yang bersifat ekspansioner, yaitu perubahan pengeluaran lebih besar dari pada perubahan pendapatan pemerintah yang berasal dari masyarakat, khususnya pajak, akan berpengaruh positif terhadap output nasional dan tingkat pendapatan masyarakat. Kebijakan fiskal yang demikian ditunjukkan oleh adanya kebijakan anggaran defisit. Peningkatan defisit anggaran pemerintah juga akan meningkatkan permintaan agregat (Parkin dan Bade, 1992; Fischer dan Dornbusch, 1994). Komponen permintaan agregat adalah konsumsi rumah tangga, investasi oleh swasta, pengeluaran pemerintah dan ekspor neto. Dengan demikian dapat dikatakan bahwa defisit anggaran akan berpengaruh pula terhadap pertumbuhan pengeluaran pemerintah (Bortle, 1995).

Sumber utama pendanaan pemerintah adalah pajak. Dengan demikian pertumbuhan pengeluaran pemerintah juga 
dipengaruhi oleh pertumbuhan penerimaan dari pajak (Hyman, 1996: 11). Kemampuan dan besarnya pembayaran pajak yang dilakukan oleh masyarakat tergantung dari tingkat pendapatan masyarakat. Dalam aspek negara pendapatan ini merupakan pendapatan nasional. Jadi pengeluaran pemerintah juga sangat dipengaruhi oleh tingkat pendapatan nasional. Secara ekonomis mekanisme ini dapat dipahami, karena pengeluaran pemerintah akan mendorong aktivitas ekonomi nasional. Pada akhirnya kenaikan aktivitas perekonomian nasional tersebut akan berdampak positif terhadap tingkat pendapatan masyarakat sehingga kemampuan membayar pajak juga meningkat. Dengan kata lain terjadi hubungan timbal balik antara pengeluaran pemerintah dan tingkat pendapatan nasional (Hondroyiannis dan Papapetrue, 1996).

Analisis terhadap kualitas pengelolaan anggaran di Indonesia dilakukan oleh Jaka Sriyana (2000). Hasil analisis dapat dilihat pada tabel 4. Dari analisis tersebut diketahui, bahwa perubahan kenaikan jumlah penduduk tidak berdampak pada peningkatan perubahan permintaan terhadap pengeluaran pemerintah dalam jangka pendek, namun memiliki pengaruh dalam jangka panjang. Bahkan ditemukan pula bahwa kenaikan perubahan pengeluaran pemerintah tidak didasarkan pada-kebutuhan masyarakat, tetapi lebih dipengaruhi oleh kemauan politik pemerintah. Kondisi tersebut menunjukkan pula rendahnya degree of publicness pengeluaran pemerintah. Dari perhitungan dapat pula diketahui bahwa dalam jangka panjang degree of publicness semakin rendah. Dengan demikian dapat diambil kesimpulan bahwa semakin besar pengeluaran pemerintah justru akan semakin kecil tercapainya sasaran kepada tiap individu masyarakat (terjadi ilusi fiskal). Hal lain yang cukup penting untuk diperhatikan adalah nilai koefisien produktivitas pengeluaran pemerintah. Dari hasil perhitungan menunjukkan bahwa derajat produktivitas pengeluaran pemerintah semakin lama ternyata semakin rendah. Hal ini juga dapat disimpulkan bahwa semakin besar pengeluaran pemerintah justru semakin kecil produktivitasnya. Temuan ini menunjukkan bahwa pengelolaan anggaran di Indonesia masih memiliki kualitas yang rendah, apalagi dibandingkan dengan negara lain. Jika fenomena ini berlangsung lama, maka akan menimbulkan terjadinya krisis fiskal, yang ditandai oleh ketidakmampuan pemerintah melaksanakan kewajiban keuangan terhadap pihak luar negeri. Untuk itu perlu adanya usaha-usaha untuk menggali sumber-sumber penerimaan dalam negeri yang dapat diandalkan untuk membiayai pembangunan. 
Topik: Optimalisasi Pengelolaan Anggaran, Hindari Krisis Fiskal, Jaka Sriyana

Tabel 4

Hasil Penghitungan Nilai Koefisien Produktivitas dan Degree of Publicness

\begin{tabular}{|l|l|c|c|}
\hline Negara & \multicolumn{1}{|c|}{ Indlkator } & $\begin{array}{c}\text { Jangka } \\
\text { Pendek }\end{array}$ & $\begin{array}{c}\text { Jangka } \\
\text { Panjang }\end{array}$ \\
\hline Indonesia & Koef. Produktivitas & 1,602 & 1,380 \\
& Degree of Publicness & 2,760 & 1,727 \\
United" & Koef. Produktivitas & 1,79 & 27,5 \\
Kingdom & Degree of Publicness & 8,83 & 87,5 \\
\hline
\end{tabular}

Sumber: Jaka Sriyana, 2000.

*) Untuk United Kingdom berdasarkan penemuan Tridimas (1992).

\section{Potensi Pajak dan Pengelolaannya}

Salah satu usaha untuk menggali sumber penerimaan pemerintahan dalam mengintensifkan penerimaan dari sektor perpajakan. Langkah yang paling utama untuk menentukan pos nilai penerimaan pajak dalam anggaran adalah dengan menghitung nilai potensi pajak yang dapat diraih. Berdasarkan pendekatan makroekonomi, maka potensi pajak dapat dihitung sebagai berikut:

\section{Potensi Pajak (T) $=[(($ COR $\times$ g) - MPS+ a $) / M P C] \times$ PDB}

Jika COR diasumsikan sebesar 5 , MPS dan MPC masing-masing 0,2 dan 0,8 , sedangkan a adalah proporsi pengeluaran pemerintah terhadap PDB serta data lain merujuk pada tabel.3, maka dapat diperoleh nilai potensi pajak tahun
2000 dan tahun 2001 masing-masing sebesar Rp. 245,7 Trilyun dan Rp.396,3 Trilyun. Untuk melihat seberapa besar nilai pajak yang 'hilang' karena tidak diperhitungkan dalam APBN dapat dilihat pada tabel 4.

Tabel 5.

Potensi dan Hilangnya Pajak Tahun 2000-2001 (Rp.Trilyun)

\begin{tabular}{|l|c|l|}
\hline & Tahun 2000 & Tahun 2001 \\
\hline Potensi Pajak & 245,7 & 396,3 \\
Direncanakan APBN & 101,4 & 179,8 \\
Pajak yang hilang & 144,3 & 216,5 \\
\hline
\end{tabular}


Dari hasil nilai pajak yang hilang tersebut menunjukkan bahwa pemerintah belum menentukan nilai pajak sesuai dengan potensinya. Dengan kata lain nilai pajak yang masih dapat diraih oleh pemerintah sebenarnya masih cukup besar, bahkan lebih dari 100\%-nya. Pada tahun 2000 total potensi pajak mencapai $80 \%$ dari total belanja negara, sedangkan tahun potensi pajak 2001 melebihi nilai belanja negara total. Untuk itu perlu usaha-usaha yang harus dilakukan oleh pemerintah untuk meningkatkan penerimaan pajak, sehingga potensi pajak yang cukup besar tersebut dapat diraih. Ada beberapa hal yang mungkin dapat dilakukan, yaitu:

1). Tentukan potensi pajak masing-masing jenis pajak dan masing-masing daerah, kemudian targetkan penerimaan pajak yang harus diraih.

2). Melakukan efisiensi pada administrasi dan biaya pemungutan pajak sehingga akan menekan kebocoran yang terjadi.

3). Memperbaiki sistem pemungutan dan pelaporan sehingga akan memudahkan kontrol terhadap pelaksanaan pemungutan pajak.

4). Merubah sistem pemungutan pajak. Jika selama ini wajib pajak harus melaporkan ke kantor pajak, maka dengan kemajuan teknologi informasi dapat dilakukan dengan mekanisme yang lebih mudah. Tentu saja sistem ini menuntut adanya seritralisasi pada penerimaan pajak.

5). Mengurangi birokrasi yang ada pada kantor perpajakan, bahkan.jika mungkin direktorat jendral pajak dapat dipisahkan dari departemen keuangan, sehingga menjadi badan tersendiri. Hal ini akan dapat meningkatkan efisiensi pengelolaan pajak, baik dari segi penerimaan maupun pelaporannya.

6). Peningkatan kualitas sumber daya manusia yang berkaitan dengan pelayanan dan pemungutan pajak mutlak dilakukan. Di samping itu peningkatan etos kerja juga harus dilakukan di semua lini.

7). Transparansi pelaporan nilai pajak harus dapat diakses oleh publik, sehingga akan meningkatkan kepercayaan masyarakat terhadap pengelolaan pajak oleh birokrat. Dengan telah berkembangnya teknologi informasi. Akses ini akan dengan mudah dapat dilakukan oleh masyarakat, sehingga akan mendorong kesadaran masyarakat wajib pajak untuk membayar pajak

\section{Kesimpulan}

Dari analisis terhadap pengelolaan anggaran di Indonesia, maka dapat dikemukakan beberapa kesimpulan sebagai berikut, pertama, kebijakan defisit anggaran yang diterapkan oleh pemerintah memiliki dampak pada peningkatan beban bagi pemerintah dalam pembiayaan pembangunan. Kedua, produktivitas dan, degree of publicness pengeluaran pemerintah yang rendah, indikasi terjadinya terjadi ilusi fiskal, memberikan implikasi bahwa efisiensi pengeluaran pemerintah masih rendah. Ketiga, penetapan pos nilai pajak dalam APBN tidak didasarkan pada potensi yang ada, sehingga ada nilai pajak yang hilang, bahkan nilai ini cukup besar dan dapat digunakan untuk menutup defisit anggaran. Keempat, pemerintah harus melakukan usaha-usaha untuk menggali potensi pajak yang hilang, sehingga akan menghindarkan ketergantungan penerimaan negara dari hutang luar negeri dan mencegah terjadinya krisis fiskal yang lebih besar. 
Topik: Optimalisasi Pengelolaan Anggaran, Hindari Krisis Fiskal, Jaka Sriyana

\section{Daftar Pustaka}

Adji, A.D, 1998, "Do Budget Deficits Raise Current Account Deficits? Cases in Asean-5" Jurnal Ekonomi dan Bisnis Indonesia , Vol.13 No.2, 15 - 28.

Barry, F., dan M.B. Devereux, 1995, "The Expansionary Fiscal Contraction Hypothesis: A Neo - Keynesian Analysis", Oxford Economic Papers, 47, 249-264.

Beetsmaa, R.M.W.J. dan F. Van der Ploeg, 1996, "Does Inequility Cause Inflation ?: The Political Economy of Inflation, Taxation and Government Debt", Public Choice, 87, 143 -162.

Bernheim, B.D., 1989, "A Neoclassical Perspective on Budget Deficit", Journal of Economic Perspectives, Vol. 3, No. 2, 55 - 72.

Bruno H. dan Carine Smolders, 1994, "Fiscal Illusion at The Local Level: Empirical Evidence for The Flemish Municipalities", Public Choice No. 80,325 - 338.

Chao, C.C., dan Edden S.H. Yu, 1993, "Can Fiscal Spending Be Contractionary in The Neoclassical Economy?", Economica, 60, 347 - 356.

Dallen, Hendick P.V. dan Otto H Swank, 1996, "Govemment Spending Cycles: Ideological or Opportunistic ?", Public Choice No. 89, 183 - 200.

Dimsdale, N.H. dan N. Horsewood, 1995, "Fiscal Policy and Employment in Interwar Britain: Some Evidence from A New Model", Oxford Economic Papers, No. 47, 369 -396.

Dornbusch, R dan S Fischer, 1994, Macroeconomics, Mc-Graw Hill, Co.
Dumairy, 1996, Perekonomian Indonesia, Erlangga, Jakarta.

Eisner, R., 1989, "Budget Deficit: Rethoric and Reality" Journal Of Economic Perspectives, Vol. 3, No.2 , 73 - 93.

Engle, R.F. dan C.W.J. Granger, 1987, "Cointegration and Error Correction: Representation, Estimation and Testing", Econometrica, 55, 251-276.

Feers, J.S. dan Edwin G West, 1996, "The Cost Deseas af Government Growth: Qualifications to Boumal", Public Choice No. 89, 35 - 52.

Handayani, Dwi Pujiastuti, 1997", Pengeluaran Pemerintah: Peran dan Implikasinya Terhadap Pertumbuhan dan Stabilitas Ekonomi Indonesia Selama Pembangunan Jangka Panjang Pertama ", Tesis S2, Program MEP, Program Pasca Sarjana, Universitas Gadjahmada, Yogyakarta, tidak dipublikasikan.

Hataiseree, R., 1995, "Cointegration Test of Purchasing Power Parity: The Case of The Thai Baht", Asian Economic Joumal, Vol. 9, No. 11, 57 69.

Hill, Hal, 1996, Transformasi Ekonomi Indonesia Sejak 1966, Penerbit PAUUGM bekerjasama dengan Tiara Wacana, Yogyakarta.

Hondroyiannis, $G$ dan Evangela $P, 1996$, "An Examination of The Causal Relationship Between Government Spending and Revenue: A Cointegration and ECM Analysis", Public Choice No. 89, 363 - 374.

Hyman, David.N, 1996 Public Finance: A Contemporary Aplications of Theory to Policies, 5th ed, The Dryden Press. 
Jayaraman, T.K., 1993, "Fiscal deficits and Current Account Imbalances of The South Pacific Countries", Occasional Paper, ADB, Dec. 1993,

Karseno, A.R., 1997, "Masalah Kemandirian di dalam Perekonomian Indonesia" dalam Liberalisasi Ekonomi dan Politik di Indonesia, Penerbit kerjasama PPM-FE UII dan PT.-Tiara Wacana, Yogyakarta.

Kuncoro, H.W., 1999, "Pengeluaran

Pemerintah dan Responsivitas

Sektor Swasta", Manuscript Jurnal Ekonomi Pembangunan, Vol. 4, No.1 (Akan terbit)

Mansoer, F.W. dan Aris Soelistyo, 1998, "Suatu Pendekatan Ekonometri Terhadap Ekonomi Makro Indonesia 1978-1994", Jurnal Ekonomi dan Bisnis Indonesia, Vol. 13, No.4, 30 50.

Miller, S., dan S. Russek, 1997, "Fiscal Structures and Economic Growth at The State and Local Level", Public Finance Review, Vol. 25, No. 2, 213 $-237$.

Nunes, J.C., dan L. Stemitsiotis, 1995, "Budget Deficit and Interest Rate: is There a Link? International Evidence", Oxford Bulletin of Economics and Statistics, 57, 4, 425 - 449.

Parkin, M dan Bade, R., 1992, Macroeconomics, Prentice Hall, New Jersey.

Petrovic, P., 1995, "Quasi Fiscal Deficit and Money Demand in Yugoslavia's high Inflation: Some Econometric
Evidence", Journal of Comparative Economics 20, 32 - 48.

Rose, D.C. dan D. R. Hakes, 1995, "Deficits and Interest Rates as Evidence of Ricardiance Equivalence", Eastern Economic Journal, Vol. 21, No. 1, 57-81.

Shah, A.M., 1992, "Empirical Tests for Allocative Efficiency in Te Local Public Sector", Quarterly Public Finance, Vol. 20, №. 3, 359 - 377.

Sheehey, E.J., 1993, "The Effect of Government Size on Economic Growth", Eastern Economic Journal, Vol. 19, No. 3, 321 - 328.

Sriyana, Jaka, 2000, "Produktivitas dan Efisiensi Pengeluaran Pemerintah di Indonesia", Jurnal Kajian Bisnis, STIE Widya Wiwaha, Yogyakarta.

Syahrizal, 1996,"Identifikasi Faktor-Faktor yang Berpengaruh Pada Bantuan Pembangunan di Propinsi Riau", Tesis S2, MEP-UGM, Yogyakarta, tidak dipublikasikan.

Tridimas, George, 1992, "Budgetary Deficits and Govemment Expenditure Growth: Toward A More Accurate Empirical Specification", Public Finance Quarterly, Vol. 20 No. 3, 275-1297.

Weiss, John, 1995, Economic Policy in Developing Countries: The Reform Agenda, Prentice Hall.

Wolfson, M.H., 1995, "Corporate Restructuring and The Budget Deficit Debate", Eastern Economic Journal, Vol. 19, No.4, 494-519. 